\begin{tabular}{lllll}
$\begin{array}{l}\text { Abstract 1302 Table } 1 \\
\text { ldentification Rates }\end{array}$ & \multicolumn{1}{l}{ SLICC Classification Criteria Attribute } \\
\hline Criterion & All Patients & $\begin{array}{l}\text { No SLE } \\
\text { Diagnoses }\end{array}$ & $\begin{array}{l}\geq 3 \text { SLE } \\
\text { Diagnoses }\end{array}$ & $\begin{array}{l}\text { p (No SLE } \\
\text { vs. } \geq 3)\end{array}$ \\
\hline Oral Ulcer & $26079(2.1 \%)$ & $25760(2.1 \%)$ & $227(3.5 \%)$ & $8.45 \mathrm{E}-14$ \\
Alopecia & $30092(2.5 \%)$ & $29598(2.5 \%)$ & $327(5 \%)$ & $4.03 \mathrm{E}-40$ \\
SLICC Neurological & $214984(18 \%)$ & $212624(18 \%)$ & $1462(23 \%)$ & $2.78 \mathrm{E}-24$ \\
Arthritis & $30693(2.5 \%)$ & $29949(2.5 \%)$ & $442(6.8 \%)$ & $1.82 \mathrm{E}-107$ \\
Serositis & $87479(7.2 \%)$ & $85870(7.1 \%)$ & $1133(17 \%)$ & $8.83 \mathrm{E}-225$ \\
Acute Cutaneous Lupus & $3644(0.3 \%)$ & $2062(0.17 \%)$ & $1256(19 \%)$ & $<2.23 \mathrm{e}-308$ \\
Chronic Cutaneous & $2704(0.22 \%)$ & $1221(0.1 \%)$ & $1141(18 \%)$ & $<2.23 \mathrm{e}-308$ \\
Lupus & & & & \\
SLICC Renal & $127890(11 \%)$ & $125377(10 \%)$ & $1866(29 \%)$ & $<2.23 \mathrm{e}-308$ \\
Thrombocytopenia & $77681(6.4 \%)$ & $76313(6.3 \%)$ & $928(14 \%)$ & $1.02 \mathrm{E}-149$ \\
Leukopenia & $808840(67 \%)$ & $800966(67 \%)$ & $4989(77 \%)$ & $1.56 \mathrm{E}-68$ \\
Hemolytic Anemia & $17123(1.4 \%)$ & $16672(1.4 \%)$ & $314(4.8 \%)$ & $1.71 \mathrm{E}-121$ \\
Antinuclear Antibodies & $28842(2.4 \%)$ & $26257(2.2 \%)$ & $1715(26 \%)$ & $<2.23 \mathrm{e}-308$ \\
Anti-Dsdna Antibodies & $22867(1.9 \%)$ & $19136(1.6 \%)$ & $2706(42 \%)$ & $<2.23 \mathrm{e}-308$ \\
Anti-Sm Antibodies & $1473(0.12 \%)$ & $936(0.078 \%)$ & $388(6 \%)$ & $<2.23 \mathrm{e}-308$ \\
Antiphospholipid & $3774(0.31 \%)$ & $3139(0.26 \%)$ & $458(7.1 \%)$ & $<2.23 \mathrm{e}-308$ \\
Antibodies & & & & \\
Direct Coombs Test & $809(0.067 \%)$ & $691(0.057 \%)$ & $91(1.4 \%)$ & $<2.23 \mathrm{e}-308$ \\
Complement & $9696(0.8 \%)$ & $6707(0.56 \%)$ & $2401(37 \%)$ & $<2.23 \mathrm{e}-308$ \\
\hline & & & &
\end{tabular}

SLE diagnostic codes: 1,201,999 persons with no diagnosis codes for SLE. All criteria items occurred significantly more often in persons with SLE compared with those without SLE and the greatest differences in SLICC attributes identified: Acute Cutaneous: $19 \%$ v. $0.17 \%$; Chronic Cutaneous: $18 \%$ vs. $0.1 \%$, Renal: $29 \%$ vs. $10 \%$, Thrombocytopenia: $14 \%$ vs. $6.3 \%$, Antinuclear Antibodies: $26 \%$ vs. $2.2 \%$, Anti-dsDNA Antibodies: $42 \%$ vs. $1.6 \%$, Anti-Sm Antibodies: $6 \%$ vs. 0.08\%, Antiphospholipid Antibodies: $7.1 \%$ vs. 0.26\%, Low complement: $37 \%$ vs. $0.6 \%$, Direct Coombs Test: $1.4 \%$ vs. $0.06 \%$. There were 2770 persons (43\%) among those $\geq 3$ SLE diagnoses and 9770 persons $(0.81 \%)$ without SLE satisfying the SLICC definition of 'Definite SLE'.

Conclusions The results demonstrate identification of all SLICC classification criteria attributes in the CAPriCORN data set, an increased rate of attribute identification for all SLICC criteria, and an increased rate of definite SLE classification via SLICC in persons with $\geq 3$ SLE diagnostic codes compared to those without SLE diagnostic codes. This suggests that SLE presentation can be characterized in CDRN data.

Acknowledgements The authors received funding support provided by grants from the National Institute of Arthritis and Musculoskeletal Disease (5R21AR072262 and P30AR072579) and the National Human Genome Research Institute (U01HG008657).

\section{THE NEW EULAR/ACR 2019 SLE CLASSIFICATION CRITERIA: A PREDICTOR OF LONG-TERM OUTCOMES}

Laura Whittall-Garcia, Murray B Urowitz*, Dafna D Gladman, Jiandong Su, Zahi Touma, Sindhu R Johnson. University of Toronto, University Health Network, Toronto, Ontario, Canada

10.1136/lupus-2021-lupus21 century.76

Background We recently demonstrated that a EULAR/ACR classification Criteria score $\geq 20$ predicts a higher disease activity throughout the first 5 years after diagnosis. Given that disease activity is associated with damage accrual and mortality, we aimed to determine the ability of a EULAR/ACR score $\geq 20$ to predict these long-term outcomes.

Methods Inception SLE patients recruited in the first 12 months after diagnosis were included.

For each patient a EULAR/ACR score was calculated based on the baseline clinical and laboratory information. The baseline information was obtained from the first 2 visits.

Patients were divided into 2 groups depending on their EULAR/ACR score $<20$ or $>20$. In order to determine the ability of a EULAR/ACR $\geq 20$ to predict damage accrual and mortality the following outcomes were assessed:

1. Time to first damage accrued: Defined as the first increase in SLICC/ACR Damage Index from 0 to $\geq 1$ within the first 10 years after SLE diagnosis, with death as a competing risk. 57 patients with damage at entry were excluded

2. Time to first increase in damage: Defined as any increase in the SLICC/ACR Damage Index within the first 10 years after SLE diagnosis, with death as a competing risk.

3. Mean SDI score at the 10th year of follow-up.

4. Time to death within the first 10 years after SLE diagnosis

5. Multivariable Cox Proportional regression was performed to calculate the risk and possible confounders.

Results A total of 867 inception patients were included. Table 1 shows baseline clinical characteristics of the cohort.

The proportion of patients who accrued damage within the first 10 years and the mean SDI at 10 years were significantly higher in the group of $\geq 20$. When looking at the specific domains in SDI, the group with a score $\geq 20$ at 10 years of follow-up had significantly more renal damage and a higher percentage of diabetes (table 2).

On multivariable regression analysis, after adjusting for age and ethnicity, a score $\geq 20$ continued to significantly predict damage accrual, HR 1.28 (1.04-1.57), $p=0.02$. When we excluded patients who had damage at enrollment the results were similar (table 3).

Sixty-eight $(7.8 \%)$ of patients died within the first 10 years of follow-up, the percent of deaths was higher in the group

Abstract 1303 Table 1 Demographic characteristics in our cohort at baseline. Values are expressed as mean \pm SD or $n(\%)$

\begin{tabular}{llll}
\hline Variables & $\begin{array}{l}\text { EULAR/ACR Score } \\
<20, N=415\end{array}$ & $\begin{array}{l}\text { EULAR/ACR Score } \\
\geq 20, \mathrm{~N}=452\end{array}$ & P value \\
\hline Race & $316(76.1)$ & $262(58.0)$ & $<0.001$ \\
Caucasian & $42(10.1)$ & $81(17.9)$ & 0.002 \\
Black & $20(4.8)$ & $52(11.5)$ & $<0.001$ \\
Chinese & $38.1 \pm 15.1$ & $34.5 \pm 13.1$ & $<0.001$ \\
Age, years & $0.2 \pm 0.3$ & $0.2 \pm 0.3$ & 0.86 \\
Disease duration, years & $6.3 \pm 5.4$ & $12.2 \pm 8.9$ & $<0.001$ \\
SLEDAI-2K score & $0.1 \pm 0.4$ & $0.1 \pm 0.4$ & 0.13 \\
SDI ${ }^{\text {a }}$ score & $23(5.5)$ & $34(7.5)$ & 0.24 \\
SDI ${ }^{\text {a }}>0$ & & & $<0.001$ \\
Treatment & $241(58.1)$ & $374(82.7)$ & $<0.001$ \\
GC ${ }^{b}$ use & $83(20.0)$ & $166(36.7)$ & 0.73 \\
Immunosuppressive use & $222(53.5)$ & $247(54.6)$ & \\
Antimalarial use & & & \\
& & &
\end{tabular}


Abstract 1303 Table 2 Outcomes within 10 years of follow-up. Values are expressed as mean \pm SD or $n(\%)$

\begin{tabular}{llll}
\hline Outcomes & $\begin{array}{l}\text { EULAR/ACR score } \\
<20 ~ N=415\end{array}$ & $\begin{array}{l}\text { EULAR/ACR score } \\
\geq 20 \mathrm{~N}=452\end{array}$ & P value \\
\hline Death & $24(5.8)$ & $44(9.7)$ & 0.03 \\
Time to death, years & $5.0 \pm 2.9$ & $3.6 \pm 3.1$ & 0.07 \\
Increase in SDI $^{\mathrm{a}}$ & $167(40)$ & $210(46)$ & 0.02 \\
Time to SDI $^{\mathrm{a}}$ increase, years & $2.9 \pm 2.7$ & $3.0 \pm 2.9$ & 0.52 \\
SDI $^{\text {a }}$ score & \\
SDI $^{\mathrm{a}}$ Domains & & & \\
Ocular & $0.97 \pm 1.42$ & $1.28 \pm 1.47$ & 0.03 \\
Neurologic & & & \\
Renal & $20(10.26)$ & $34(15.96)$ & 0.08 \\
Pulmonary & $19(9.74)$ & $28(13.15)$ & 0.28 \\
Cardiovascular & $5(2.56)$ & $19(8.92)$ & 0.006 \\
Vascular & $3(1.54)$ & $9(4.23)$ & 0.10 \\
Gastrointestinal & $22(11.28)$ & $14(6.57)$ & 0.09 \\
Muskuloeskeletal & $6(3.08)$ & $8(3.76)$ & 0.70 \\
Skin & $5(2.56)$ & $6(2.82)$ & 0.87 \\
Gonadal & $38(19.49)$ & $54(25.35)$ & 0.15 \\
Diabetes & $18(9.23)$ & $21(9.86)$ & 0.82 \\
Malignancy & $1(0.51)$ & $3(1.41)$ & 0.35 \\
\hline At & $3(1.54)$ & $14(6.57)$ & 0.01 \\
& $5(2.56)$ & $3(1.41)$ & 0.40 \\
\hline
\end{tabular}

${ }^{\#}$ At 10 years of follow-up, $\mathrm{N}=190$ and 206 in the low and high score groups respectively. asLICC/ACR Damage Index

Abstract 1303 Table 3 Univariate and Multivariable Cox Regression analysis. Factors associated with damage accrual and death within 10 years of follow-up

\begin{tabular}{|c|c|c|c|c|}
\hline & \multicolumn{2}{|c|}{ Univariate Cox Regression } & \multicolumn{2}{|c|}{$\begin{array}{l}\text { Multivariable Cox } \\
\text { Regression }\end{array}$} \\
\hline \multicolumn{5}{|c|}{ First damage accrued (any increase in $\mathrm{SDI}^{\mathrm{a}}$ ) } \\
\hline VARIABLE & $\begin{array}{l}\text { Hazard Ratio } \\
(95 \% \mathrm{Cl})\end{array}$ & $P$ value & $\begin{array}{l}\text { Hazard Ratio } \\
(95 \% \mathrm{Cl})\end{array}$ & $P$ value \\
\hline Age at first visit & $1.02(1.01-1.03)$ & $<0.001$ & $1.02(1.01-1.03)$ & $<0.001$ \\
\hline $\begin{array}{l}\text { Caucasian vs non- } \\
\text { caucasian }\end{array}$ & $0.88(0.71-1.08)$ & 0.22 & $0.89(0.72-1.11)$ & 0.31 \\
\hline $\begin{array}{l}\text { EULAR/ACR score }<\text { or } \\
\geq 20\end{array}$ & $1.21(0.98-1.48)$ & 0.07 & $1.3(1.04-1.57)$ & 0.02 \\
\hline \multicolumn{5}{|c|}{ First damage accrued (Initial SDI $\left.{ }^{\mathrm{a}}>0\right)^{\#}$} \\
\hline Age at first visit & $1.02(1.01-1.03)$ & $<0.001$ & $1.02(1.02-1.03)$ & $<0.001$ \\
\hline $\begin{array}{l}\text { Caucasian vs non- } \\
\text { caucasian }\end{array}$ & $0.88(0.71-1.10)$ & 0.27 & $0.91(0.73-1.14)$ & 0.42 \\
\hline $\begin{array}{l}\text { EULAR/ACR score }<\text { or } \\
\geq 20\end{array}$ & $1.25(1.01-1.54)$ & 0.04 & $1.33(1.07-1.64)$ & 0.009 \\
\hline \multicolumn{5}{|c|}{ Mortality } \\
\hline Age at first visit & $1.05(1.03-1.06)$ & $<0.001$ & $1.05(1.03-1.07)$ & $<0.001$ \\
\hline $\begin{array}{l}\text { Caucasian vs non- } \\
\text { caucasian }\end{array}$ & $1.46(0.84-2.57)$ & 0.17 & $1.48(0.84-2.62)$ & 0.17 \\
\hline $\begin{array}{l}\text { EULAR/ACR score }<\text { or } \\
\geq 20\end{array}$ & $1.66(1.01-2.73)$ & 0.04 & $2.13(1.28-3.54)$ & 0.003 \\
\hline
\end{tabular}

\#57 patients who had damage at entry were excluded for the analysis. aLICC/ACR Damage Index.

with a score $\geq 20$, (table 2 ). Individuals in the $\geq 20$ group had twice the probability of dying compared to patients with the lower score, the hazard ratios with significant $p$ values confirmed this finding (table 3).

Conclusion A EULAR/ACR score $\geq 20$ is an indicator of damage accrual and mortality in SLE.

\section{FACTORS IN LUPUS DIAGNOSIS}

${ }^{1}$ Daria McClamb*, ${ }^{2}$ Lydia Oberholtzer, ${ }^{1}$ Ashley Marion, 'Lauren Topf, 'Mary Crimmings, 'Karin Tse, ${ }^{3}$ John Wegener, ${ }^{3}$ Valerie Melucci, ${ }^{3}$ Tyler O'Malley, ${ }^{3}$ Debra Zack, ${ }^{4}$ Donald E Thomas. 'Lupus Foundation of America, Washington, DC; ${ }^{2}$ Sharp Insight, Montgomery County, Maryland; ${ }^{3}$ Exagen Inc., Vista, CA; ${ }^{4}$ Arthritis and Pain Associates of PG County

\subsection{6/lupus-2021-lupus21 century.77}

Background Lupus is a complex, chronic autoimmune disease affecting an estimated 1.5 million Americans.

Lupus symptoms are heterogeneous. Suboptimal diagnostic tests have contributed to diagnostic delay. Reducing diagnostic time is critical to preventing poor long-term outcomes. An objective of the 2020 survey sought to understand how access to healthcare is associated with diagnostic delay factors.

Methods A 25-question retrospective cross-sectional online survey on diagnostic time factors was developed by the Lupus Foundation of America (LFA) in partnership with Exagen. Using convenience sampling, individuals who self-reported SLE were recruited and 1,313 responded. Descriptive statistics and chi-square tests were conducted.

Results Almost half of respondents (45.4\%) were diagnosed within a year of their first health care provider visit to discuss symptoms, while $29.1 \%$ reported five or more years to diagnosis. Factors delaying diagnosis may include misdiagnosis and the number of visited doctors. On average, respondents saw 2.8 different types of doctors before diagnosis. Nearly a third reported they were diagnosed with anxiety (31.7\%), depression $(29.8 \%)$, or fibromyalgia $(23.0 \%)$ before their lupus diagnosis, and $21.8 \%$ were told nothing was wrong with them.

Decreased care access and high costs associated with delayed lupus diagnosis. More than a third (35.9\%) of respondents diagnosed after five or more years reported that out-of-pocket costs were too high, compared to $22.8 \%$ diagnosed within a year (table 1). Over half diagnosed after a year cited long wait times for specialist appointments,

Abstract 1304 Table 1 Challenges to Care in Lupus Diagnosis and Time to Diagnosis (N-1,302)

\begin{tabular}{|c|c|c|}
\hline Challenge Reported & Percent of Respondents (\%) & P-value \\
\hline Out-of-pocket costs too high & & 0.001 \\
\hline$<1$ year & 22.8 & \\
\hline $1-4$ years & 35.2 & \\
\hline $5+$ years & 35.9 & \\
\hline Long wait times for specialists & & 0.001 \\
\hline$<1$ year & 39.4 & \\
\hline $1-4$ years & 55.4 & \\
\hline $5+$ years & 58.3 & \\
\hline Insurance did not cover costs of services & & 0.003 \\
\hline$<1$ year & 8.6 & \\
\hline $1-4$ years & 13.9 & \\
\hline $5+$ years & 15.3 & \\
\hline Long wait times for PCP & & 0.001 \\
\hline$<1$ year & 8.3 & \\
\hline $1-4$ years & 15.4 & \\
\hline $5+$ years & 17.2 & \\
\hline Not enough doctors nearby to treat Lupus & & 0.03 \\
\hline$<1$ year & 25.2 & \\
\hline $1-4$ years & 32.2 & \\
\hline $5+$ years & 31.9 & \\
\hline
\end{tabular}

